\title{
PERKEMBANGAN RISET DI BIDANG NEUROCOMPUTING
}

\author{
Zen Munawar, ST, S.Kom., M.Kom \\ Dosen Tetap Prodi Manajemen Informatika \\ Politeknik LP3I Bandung \\ E-mail:munawarzen@gmail.com
}

\begin{abstract}
Abstrak : Neurocomputing didefinisikan adalah proses komputasi berdasarkan cara otak bekerja, dan proses emulasi saraf primitif dalam perangkat lunak atau perangkat keras. Neurocomputing berkaitan dengan jaringan saraf (neural network). Karakteristik neural network pertama secara filosofis terdiri dari learning. generalization, abstraction, applicability dan kedua secara teknis terdiri dari node, characteristics, topology, learning rules. Berdasarkan kajian dari pengamatan literatur oleh penulis, banyak publikasi penelitian mengenai aplikasi neurocomputing yang dibuat oleh beberapa peneliti. Makalah ini memperkenalkan bidang jaringan saraf dengan menghadirkan kerangka untuk merancang ANN (model neuron, struktur jaringan dan algoritma pembelajaran), dan kemudian melanjutkan dengan review dari beberapa jenis yang paling terkenal dari jaringan saraf. Beberapa contoh aplikasi dari semua jaringan akan disajikan dalam makalah ini.
\end{abstract}

Kata kunci : Neurocomputing, neural network, online, learning rules.

\section{Pendahuluan}

Terdapat beberapa contoh pertanyaan yang paling menantang dalam ilmu. Bagaimana informasi proses otak? Bagaimana semua itu diatur? Apa biologis mekanisme yang terlibat dalam fungsi otak?. Otak sangat baik dalam melakukan fungsi seperti pengenalan pola, kontrol motor, persepsi, inferensi fleksibel, intuisi, dan menebak. Tetapi otak juga lambat, tidak tepat, membuat generalisasi yang keliru, berprasangka, dan biasanya mampu menjelaskan tindakan mereka sendiri.

Neurocomputing, kadang-kadang disebut komputasi otak seperti atau neurocomputation tapi paling sering disebut sebagai jaringan saraf tiruan (Anderson, 1995), dapat didefinisikan sebagai informasi sistem pengolahan (perangkat komputasi) dirancang dengan inspirasi yang diambil dari saraf sistem, lebih khusus otak, dan dengan penekanan khusus dalam pemecahan masalah.

Neurocomputing didefinisikan adalah proses komputasi berdasarkan cara otak bekerja, dan proses emulasi saraf primitif dalam perangkat lunak atau perangkat keras. Neurocomputing berkaitan dengan jaringan saraf (neural network) (Fredric M. Ham, 2001). Karakteristik neural network pertama secara filosofis terdiri dari learning. generalization, abstraction, applicability dan kedua secara teknis terdiri dari node, characteristics, topology, learning rules. 
Di sekeliling kita terdapat banyak contoh dari berbagai masalah yang berkarakteristik demikian, antara lain : bagaimana kita mampu membaca berbagai macam corak tulisan tangan, atau bahkan pada tulisan itu ada sebagian yang terhapus, bagaimana membuat $\mathrm{AC}$ agar mengatur sendiri suhunya otomatis, sehingga udara di dalam ruang terasa nyaman, bagaimana mengenali seseorang, padahal tidak seluruh wajahnya dapat terlihat.

Sistem Neurocomputing berbeda dari apa yang sekarang dikenal sebagai neuroscience komputasi, yang terutama berkaitan dengan pengembangan komputasi berbasis biologis model dari sistem saraf. Jaringan syaraf tiruan di sisi lain, mengambil inspirasi lepas dari sistem saraf dan menekankan pemecahan masalah kemampuan dari sistem yang dikembangkan. Namun, sebagian besar buku-buku tentang ilmu neuro computational tidak hanya knowledge keberadaan jaringan syaraf tiruan, tetapi juga menggunakan beberapa ide dari mereka dalam usulan model yang lebih biologis masuk akal. Mereka juga membahas jaringan saraf tiruan kesesuaian sebagai model sistem saraf nyata biologis.

Solusi berbagai masalah yang terdapat pada domain ini tidak mudah dihitung dengan berbagai model analitik yang ada. Diperlukan solusi yang seolah memiliki kecerdasan sehingga mampu menyelesaikan masalah-masalah yang demikian kompleks itu. Hal inilah yang melatarbelakangi, mengapa riset neurocomputing banyak mengambil ide dari proses informasi yang berada di dalam otak manusia.

Para ahli berusaha agar komputer bisa berpikir sama seperti cara berpikir manusia. Caranya adalah dengan melakukan peniruan terhadap aktivitas-aktivitas yang terjadi didalam sebuah jaringan saraf biologis. Ketika manusia berpikir, aktivitasaktivitas yang terjadi adalah aktivitas mengingat, memahami, menyimpan, dan memanggil kembali apa yang pernah dipelajari oleh otak. Sesungguhnya apa yang terjadi didalam otak manusia jauh lebih rumit dari apa yang telah disebutkan di atas. Para ahli bedah otak sering membicarakan mengenai adanya pengaktifan neuron, pembuatan koneksi baru, atau pelatihan kembali pola-pola tingkah laku pada otak manusia. Salah satu contoh pengambilan ide dari jaringan saraf biologis adalah adanya elemenelemen pemrosesan pada jaringan saraf tiruan yang saling terhubung dan beroperasi secara parallel. Ini meniru jaringan saraf biologis yang tersusun dari sel-sel saraf (neuron). Cara kerja dari elemen-elemen pemrosesan jaringan saraf tiruan juga sama seperti cara neuron meng-encode informasi yang diterimanya.

Terdapat perhatian utama yaitu bahwa jaringan saraf tiruan tidak diprogram untuk menghasilkan keluaran tertentu. Semua keluaran atau kesimpulan yang ditarik oleh jaringan didasarkan pada pengalamannya selama mengikuti proses pembelajaran. Jaringan saraf biologis merupakan kumpulan dari sel-sel saraf (neuron). Neuron mempunyai tugas mengolah informasi.

Komponen-komponen utama dari sebuah neuron dapat dikelompokkan menjadi 3 bagian, yaitu:

1. Dendrit. Dendrit bertugas untuk menerima informasi.

2. Badan sel (soma). Badan sel berfungsi sebagai tempat pengol;ahan informasi. 
3. Akson (neurit). Akson mengirimkan impuls-impuls ke sel saraf lainnya.

Otak manusia merupakan mesin molekuler, yang terdiri dari dua jenis sel: neuron dan glia. Dalam otak kita terdapat sekitar $10^{11}$ sel neuron, sedangkan sel glia sekitar 3 sampai 4 kali lipatnya. Sel neuron berfungsi sebagai pemroses informasi yang diterima oleh otak. Sel neuron terhubung antara satu dengan yang lain dengan benang-benang panjang. Berat otak manusia saat lahir sekitar 400 gram, sedangkan saat dewasa sekitar 1500 gram. Pertambahan berat ini disebabkan oleh bertambahpanjangnya benang-benang tersebut, disamping pertambahan sel glia. Pertambahan panjang ini berkaitan erat dengan proses pembelajaran yang dialami oleh manusia. Hal ini merupakan ide awal bagi pengembangan neurocomputing: jaringan saraf tiruan, yang memiliki kemampuan pembelajaran terhadap informasi yang telah diterima.

Hal yang ingin dicapai dengan melatih/ mengajari jaringan saraf tiruan adalah untuk mencapai keseimbangan antara kemampuan memorisasi dan generalisasi. Yang dimaksud dengan kemampuan memorisasi adalah kemampuan jaringan saraf tiruan untuk memanggil kembali secara sempurna sebuah pola yang telah dipelajari. Kemampuan generalisasi adalah kemampuan jaringan saraf tiruan untuk menghasilkan respons yang bisa diterima terhadap pola-pola input yang serupa (namun tidak identik) degan pola yang sebelumnya telah dipelajari.

Diskusi yang akan disajikan di sini secara singkat memperkenalkan aspek-aspek utama dari saraf sistem yang digunakan untuk merancang sistem neurocomputing, dan kemudian berfokus pada beberapa yang paling umum digunakan jaringan syaraf tiruan, yaitu, single dan multi-layer perceptrons, jaringan mengorganisir diri, dan jaringan Hopfield. Deskripsi dari banyak algoritma menggunakan notasi matriks sangat cocok untuk implementasi software mereka dari algoritma. Masuk akal biologis masing-masing model juga dinilai.

Makalah ini menjelaskan secara ringkas bidang yang termasuk neurocomputing, disertai dengan contoh-contoh aplikasinya yang dikerjakan oleh peneliti. Dengan demikian diharapkan dapat diperoleh wawasan pemetaan potensi dan kemampuan periset di bidang ini, yang merupakan informasi awal bagi sinergi di masa depan dalam melakukan kolaborasi antar peneliti, institusi, maupun dengan kalangan industri kususnya di Indonesia.

\section{Teori Dasar Neurocomputing}

Sistem Neurocomputing berbeda dari apa yang sekarang dikenal sebagai neuroscience komputasi, yang terutama berkaitan dengan pengembangan komputasi berbasis biologis model dari sistem saraf. Jaringan syaraf tiruan di sisi lain, mengambil inspirasi lepas dari sistem saraf dan menekankan pemecahan masalah kemampuan dari sistem yang dikembangkan. Namun, sebagian besar buku-buku tentang ilmu saraf komputasi tidak hanya ackowledge keberadaan jaringan syaraf tiruan, tetapi juga menggunakan beberapa ide dari mereka dalam usulan model yang lebih biologis masuk akal. Mereka juga membahas jaringan saraf tiruan kesesuaian sebagai model sistem saraf nyata biologis. 


\subsection{Tingkatan Organisasi dalam Sistem Saraf}

Sistem saraf terdiri dari tingkatan yang berbeda: molekul, sinapsis, neuron, jaringan, lapisan, peta, dan sistem (Gambar 2.1). Struktur yang mudah dikenali di sistem saraf adalah neuron, yang merupakan sel khusus dalam pemrosesan sinyal. tergantungpada kondisi lingkungan, neuron mampu menghasilkan sinyal, lebih khusus potensial listrik, yang digunakan untuk mengirimkan informasi ke sel-sel lain yang itu terhubung. Beberapa proses dalam neuron memanfaatkan siklus air dari reaksi biokimia yang mempengaruhi pengolahan informasi dalam sistem saraf. Banyak struktur saraf dapat diidentifikasi dengan fungsi tertentu. Misalnya sinapsis yang penting untuk pemahaman pengolahan sinyal dalam sistem saraf (Trappenberg, 2002).

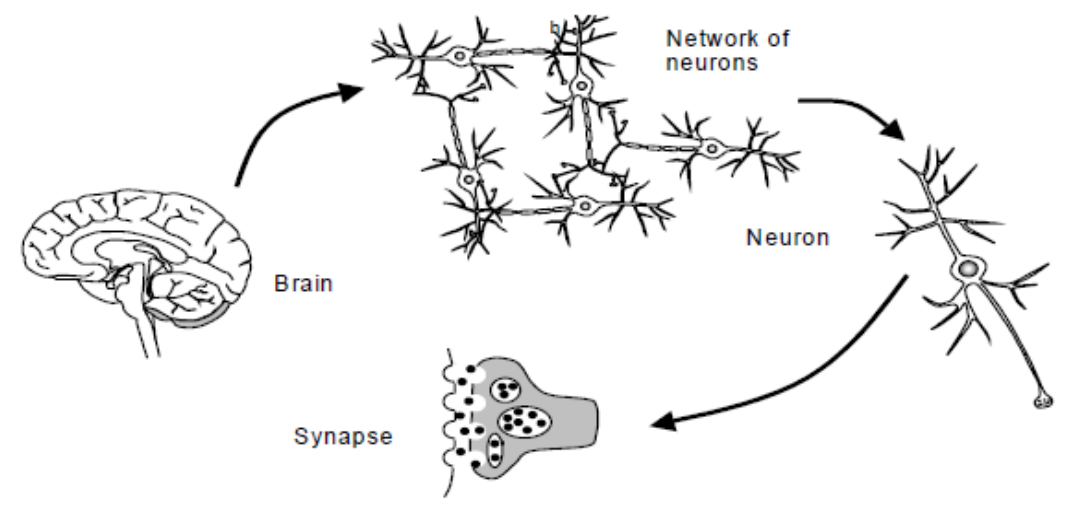

Gambar 2.1 Beberapa tingkatan organisasi dalam sistem saraf

\subsection{Dasar Biologis dan Fisik Belajar dan Memori}

Secara umum, pembelajaran global merupakan fungsi dari perubahan lokal dalam neuron. ada banyak mungkin cara neuron bisa mengubah untuk mewujudkan adaptasi. Misalnya, dendrit baru mungkin tumbuh keluar, atau mungkin ada perpanjangan cabang yang ada, atau sinapsis yang ada bisa berubah, atau sinapsis baru mungkin dibuat. Di arah lain, pemangkasan dapat menurunkan dendrit atau bit dendrit, dan dengan demikian mengurangi jumlah sinapsis, atau sinapsis di cabang-cabang yang tersisa bisa ditutup sama sekali. Ini semua postsynaptic perubahan dalam dendrit. Ada juga bisa menjadi perubahan dalam akson; contohnya, mungkin ada perubahan dalam membran, atau cabang baru mungkin terbentuk, dan gen mungkin diinduksi untuk menghasilkan neurotransmitter baru atau lebih dari yang lama. Pre-synaptic perubahan dapat mencakup perubahan jumlah vesikel dirilis per lonjakan dan nomor molekul pemancar terkandung dalam setiap vesikel. Akhirnya, seluruh sel akan mati, mengambil dengan itu semua sinapsis itu sebelumnya didukung (Churchland \& Sejnowsky, 1992).

Dua mekanisme utama yang mendasari pembelajaran dalam sistem saraf adalah long-term potentiation (LTP) dan long-term depression (LTD), yang mengacu pada penguatan dan pelemahan bobot dalam bentuk non-transien. berkoresponden potensiasi untuk peningkatan depolarisasi diukur atau eksitasi disampaikan oleh 
stimulus dikendalikan ke neuron penerima, dan depresi sesuai dengan penurunan depolarisasi diukur. Dalam kedua kasus, eksitasi atau inhibisi dari potensial membran dapat memicu urutan kejadian yang kompleks yang pada akhirnya mengakibatkan modifikasi efisiensi sinaptik (kekuatan).

Seperti belajar, memori merupakan hasil dari sebuah proses adaptif pada sambungan sinaptik. Hal ini disebabkan oleh perubahan dalam efisiensi sinaptik neuron sebagai akibat dari aktivitas saraf. Perubahan ini pada gilirannya menyebabkan jalur baru atau jalur difasilitasi untuk mengembangkan untuk transmisi sinyal melalui sirkuit saraf otak. Baru atau difasilitasi jalur disebut memori jejak; setelah dibentuk, mereka dapat diaktifkan dengan pemikiran keberatan untuk mereproduksi kenangan. Sebenarnya, salah satu hasil dari proses pembelajaran bisa penciptaan skema modifikasi sinaptik yang lebih permanen, sehingga mengakibatkan menghafal pengalaman.

Memori dapat diklasifikasikan dalam beberapa cara. Satu umum klasifikasi memori sebagai berikut :

1. Memori jangka pendek: berlangsung dari beberapa detik untuk beberapa menit - misalnya, seseorang menyimpan memori nomor telepon;

2. Memori jangka panjang menengah: berlangsung dari menit ke minggu misalnya, nama seorang gadis cantik dan Anda bertemu di sebuah pesta;

3. Memori jangka panjang: berlangsung untuk waktu yang tidak terbatas misalnya, alamat rumah Anda.

\subsection{Artificial Neural Networks}

Artificial Neural Networks (Jaringan Saraf Tiruan) menurut Haykin (Haykin, 1999) didefinisikan sebagai berikut :

"Sebuah neural network (JST: Jaringan Saraf Tiruan) adalah prosesor yang terdistribusi paralel, terbuat dari unit-unit yang sederhana, dan memiliki kemampuan untuk menyimpan pengetahuan yang diperoleh secara eksperimental dan siap pakai untuk berbagai tujuan.

Neural network ini meniru otak manusia dari sudut :

1. Pengetahuan diperoleh oleh network dari lingkungan, melalui suatu proses pembelajaran.

2. Kekuatan koneksi antar unit yang disebut synaptic weights, berfungsi untuk menyimpan pengetahuan yang telah diperoleh oleh jaringan tersebut."

Artificial Neural Networks atau Jaringan saraf tiruan (JST) menyajikan sejumlah fitur dan karakteristik kinerja kesamaan dengan sistem saraf:

1. Pengolahan informasi dasar terjadi di banyak elemen sederhana yang disebut (buatan) neuron (node atau unit);

2. neuron ini saling berhubungan sehingga membentuk jaringan neuron atau jaringan saraf; 
3. Informasi (sinyal) ditransmisikan antara neuron melalui link koneksi disebut sinapsis;

Efisiensi sinaps, diwakili oleh terkait nilai bobot atau kekuatan, sesuai dengan informasi yang disimpan dalam neuron, sehingga dalam jaringan; dan

4. Pengetahuan diperoleh dari lingkungan dengan proses yang dikenal sebagai pembelajaran yang pada dasarnya bertanggung jawab untuk mengadaptasi kekuatan koneksi (nilai berat badan) untuk rangsangan lingkungan.

Salah satu fitur penting dari jaringan saraf tiruan adalah di mana pengetahuan disimpan. Pada dasarnya, apa yang disimpan adalah kekuatan koneksi (kekuatan sinaptik) antara unit (neuron buatan) yang memungkinkan pola yang akan diciptakan. Fitur ini memiliki implikasi yang sangat besar, baik untuk pengolahan dan pembelajaran. Representasi pengetahuan diatur sehingga pengetahuan tentu mempengaruhi proses pengolahan; itu menjadi bagian dari pengolahan diri. Jika pengetahuan dimasukkan ke dalam kekuatan dari koneksi, maka belajar menjadi masalah menemukan kekuatan koneksi yang sesuai sehingga menghasilkan pola memuaskan aktivasi dalam kondisi tertentu.

\subsubsection{Typical Artificial Neural Networks}

Bagian sebelumnya memperkenalkan dasar-dasar neurocomputing. Dikatakan bahwa jaringan saraf tiruan dapat dirancang oleh 1) memilih beberapa model abstrak dari neuron, 2) mendefinisikan arsitektur jaringan, dan 3) memilih sebuah algoritma pembelajaran yang tepat. Pada bagian ini, beberapa jaringan saraf yang paling umum digunakan akan dijelaskan, berfokus pada tiga aspek utama di atas: jenis neuron, arsitektur jaringan, dan algoritma pembelajaran. Setelah 1943 McCulloch dan Pitts dalam makalahnya 'menggambarkan kalkulus logis dari aktivitas neuron, N. Wiener menerbitkan sebuah buku terkenal bernama Cybernetics pada tahun 1948, diikuti oleh publikasi buku Hebb The Organization of Behavior. Ini adalah beberapa landmark di sejarah neurocomputing.

Dalam buku Hebb, sebuah pernyataan eksplisit dari aturan belajar fisiologis untuk sinaptik modifikasi disajikan untuk pertama kalinya. Hebb mengusulkan bahwa konektivitas dari otak terus berubah sebagai suatu organisme belajar tugas fungsional yang berbeda, dan saraf yang rakitan diciptakan oleh perubahan tersebut. Hebb menyatakan bahwa efektivitas variabel sinaps antara dua neuron meningkat dengan aktivasi ulang satu neuron oleh lain di seluruh sinaps itu. Mengutip dari buku Hebb The Organisasi Perilaku: "Ketika sebuah akson dari sel A cukup dekat untuk merangsang sel B dan berulang kali atau terus-menerus mengambil bagian dalam penembakan itu, beberapa proses pertumbuhan atau perubahan metabolik terjadi dalam satu atau kedua sel sehingga A efisiensi sebagai salah satu sel menembak B, meningkat. "(Hebb, 1949; p. 62)

Teori ini mengharuskan perubahan terjadi pada kekuatan sinaptik antar sel ketika sel pra-sinaptik dan pasca-sinaptik aktif pada waktu yang sama. Hebb 
menyarankan bahwa ini Perubahan adalah dasar untuk belajar asosiatif yang akan menghasilkan modifikasi yang berlangsung di pola aktivitas didistribusikan spasial merakit neuron.

\section{Single-Layer Perceptron}

Rosenblatt $(1958,1962)$ memperkenalkan perceptron sebagai bentuk sederhana dari jaringan saraf digunakan untuk klasifikasi pola linear dipisahkan. Perceptrons merupakan yang model pertama dari pembelajaran diawasi, meskipun beberapa perceptrons yang self-organized. Sebelum menggambarkan algoritma perceptron belajar, bagian berikutnya membahas dalam beberapa lebih rinci masalah keterpisahan linear.

Linear separability dapat dengan mudah dipahami dengan contoh sederhana. Tanpa kehilangan umum, menganggap ada satu set pola masukan harus diklasifikasikan ke dalam satu kelas. Menganggap juga ada sistem classifier yang memiliki merespon TRUE jika pola masukan yang diberikan adalah anggota dari kelas tertentu, dan FALSE jika tidak. Sebuah respon TRUE diwakili oleh Output '1' dan respon FALSE oleh output '0' dari classifier.

Sebagai salah satu dari dua tanggapan diperlukan, ada batas keputusan yang membagi satu respon dari yang lain. Tergantung pada jumlah $\mathrm{m}$ variabel pola input, batas keputusan dapat memiliki bentuk dalam ruang dimensi $\mathrm{m}$. Jika $\mathrm{m}=2$ dan classifier dapat diatur sehingga ada garis membagi semua pola masukan yang menghasilkan output ' 1 ' dari pola-pola yang menghasilkan output '0', maka masalahnya adalah linear terpisah; selain itu lain itu adalah non-linear dipisahkan. Hal ini berlaku untuk ruang dimensi apapun, tapi untuk dimensi yang lebih tinggi, pesawat atau hiper-pesawat harus ada sehingga untuk membagi ruang menjadi '1'kelas dan a '0'kelas wilayah.

Gambar 2.2 menggambarkan salah satu fungsi linear dipisahkan dan satu nonlinear dipisahkan fungsi. Perhatikan bahwa, pada Gambar 2.2 (a), beberapa baris dapat ditarik sehingga untuk memisahkan data ke kelas ' 1 ' atau ' 0 '. Daerah-daerah yang memisahkan kelas yang masing-masing dari pola masukan milik sering disebut keputusan daerah, dan (hiper) permukaan yang mendefinisikan ini daerah disebut permukaan keputusan. Oleh karena itu, masalah klasifikasi dapat dilihat sebagai masalah menemukan permukaan keputusan yang benar mengklasifikasikan input data. Kesulitan berbaring di bahwa itu tidak selalu sepele untuk secara otomatis menentukan permukaan tersebut.

\begin{tabular}{c|c|c}
\multicolumn{2}{c|}{ Inputs } & Output \\
\hline$x_{1}$ & $x_{2}$ & $x_{1}$ AND $x_{2}$ \\
0 & 0 & 0 \\
0 & 1 & 0 \\
1 & 0 & 0 \\
1 & 1 & 1
\end{tabular}



(a)



(b)

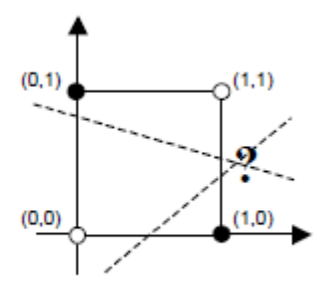

Gambar 2.2. Contoh linear dan keterpisahan non-linear. (a) fungsi Logika DAN. (b) fungsi Logika XOR. 


\section{ADALINE, the LMS Algorithm, and Error Surfaces}

Hampir pada saat yang sama Rosenblatt memperkenalkan aturan pembelajaran perceptron, B. Widrow dan muridnya M. Hoff (Widrow \& Hoff, 1960) mengembangkan pembelajaran Widrow-Hoff Aturan, juga disebut paling berarti kuadrat (LMS) algoritma atau delta aturan. mereka memperkenalkan yang ADALINE (Adaptive Linear Neuron) jaringan yang sangat mirip dengan perceptron, kecuali bahwa fungsi aktivasi adalah linear bukan ambang batas. Meskipun kedua jaringan, ADALINE dan perceptron, menderita hanya menjadi mampu memecahkan dipisahkan linear masalah, algoritma LMS lebih kuat daripada aturan pembelajaran perceptron dan memiliki menemukan banyak kegunaan yang lebih praktis daripada perceptron.

\section{Multi-Layer Perceptron}

Multi-layer perceptron adalah jenis multi-layer jaringan feedforward seperti satu diilustrasikan pada Gambar 2.3 Biasanya, jaringan terdiri dari satu set unit masukan yang merupakan lapisan input, satu atau lebih lapisan tersembunyi, dan lapisan output. Sinyal input menyebar melalui jaringan dalam arah maju, lapis demi lapis, jaringan ini adalah generalisasi dari single-layer perceptron.

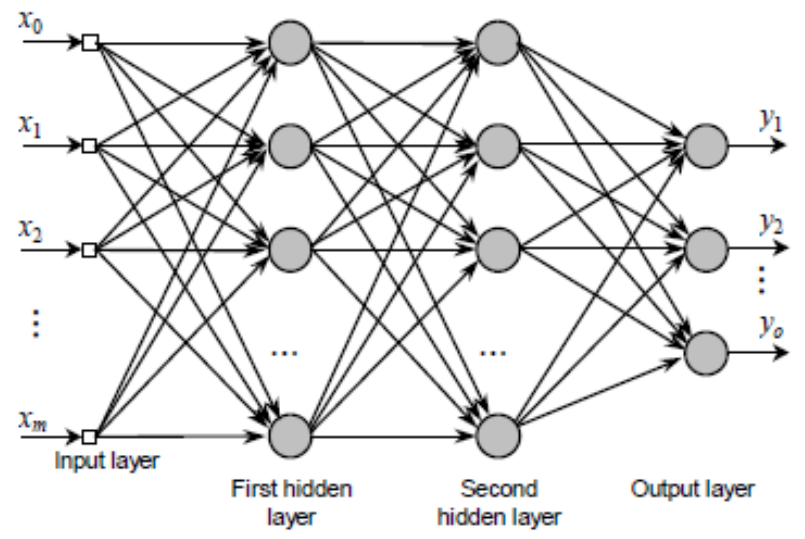

(a)

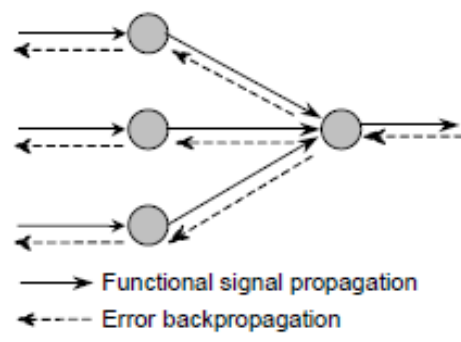

(b)

Gambar 2.3 Multi-layer jaringan saraf feedforward. (a) arsitektur jaringan (b) Arah perambatan sinyal fungsional dan kesalahan.

Akhir 1960-an, M. Minsky dan Papert S. (M. Minsky, 1969) menulis buku yang berjudul Perceptrons menunjukkan keterbatasan tunggal berlapis jaringan feedforward, yaitu, ketidakmampuan memecahkan masalah non-linear separable. Hal ini menyebabkan dampak yang signifikan kepentingan dalam penelitian jaringan saraf selama tahun 1970. Kedua, Rosenblatt dan Widrow menyadari keterbatasan jaringan perceptron dan mengusulkan jaringan multi-layer untuk mengatasi keterbatasan ini. Namun, mereka tidak dapat menggeneralisasi algoritma mereka untuk melatih jaringan ini lebih kuat. 


\section{Self-Organizing Maps}

Self-organizing map (SOM), jaringan ini diperkenalkan oleh T. Kohonen (1982). Itu arsitektur jaringan adalah a single layer feedforward network dengan postsynaptic neurons ditempatkan pada node dari kisi atau grid yang biasanya uni atau bi-dimensi, seperti yang digambarkan Gambar 2.4. Jaringan ini dilatih melalui skema pembelajaran yang kompetitif, sehingga ada lateralis hubungan antara unitunit output yang tidak ditampilkan dalam gambar.

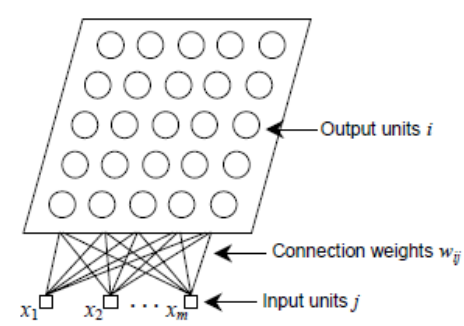

(a)

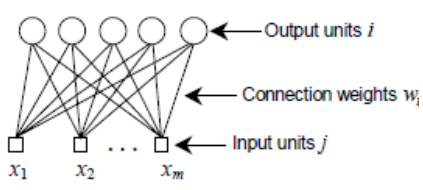

(b)

Gambar 2.4. Arsitektur khas (single layer feedforward) dari self-organized map. Bi-dimensional output grid. (b) Uni-dimensional output grid.

Unit keluaran menjadi selektif sesuai untuk berbagai pola sinyal input atau kelas pola melalui proses pembelajaran tanpa pengawasan. Dalam versi standar yang akan disajikan di sini, hanya satu neuron atau kelompok neuron lokal pada suatu waktu memberikan respon aktif ke masukan saat ini. Lokasi dari respon cenderung menjadi memerintahkan seolah-olah beberapa bermakna sistem koordinat untuk fitur input yang berbeda yang diciptakan melalui jaringan (Kohonen, 1990). Self-organizing map ditandai dengan pembentukan topografi suatu peta pola masukan di mana lokasi spasial atau koordinat neuron di jaringan merupakan indikasi dari fitur statistik intrinsik yang terkandung dalam pola masukan tersebut.

\section{Discrete Hopfield Network}

J. Hopfield $(1982,1984)$ menyadari bahwa dalam sistem fisik terdiri dari sejumlah besar unsur-unsur sederhana, interaksi antara sejumlah besar komponen dasar menghasilkan kompleks fenomena kolektif, seperti orientasi magnetik yang stabil dan domain dalam sistem magnetik atau pola pusaran dalam aliran fluida. Terutama, Hopfield melihat bahwa ada kelas dari sistem fisik yang perilakunya spontan dapat digunakan sebagai bentuk umum dan mengoreksi kesalahan content-addressable memory (CAM). Fungsi utama dari memori-konten addressable, juga disebut memori asosiatif, adalah untuk mengambil pola disimpan dalam memori sebagai respon terhadap penyajian versi lengkap atau bising pola itu, seperti yang diilustrasikan pada Gambar 2.5. Dalam CAM, memori tercapai tidak dengan mengetahui alamatnya, melainkan dengan menyediakan beberapa sub bagian dari memori. 

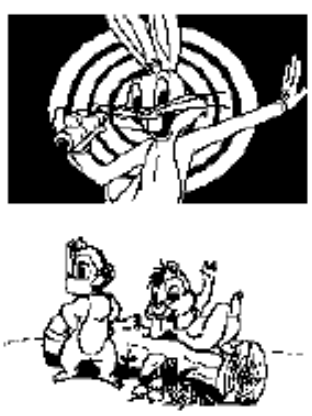

(a)
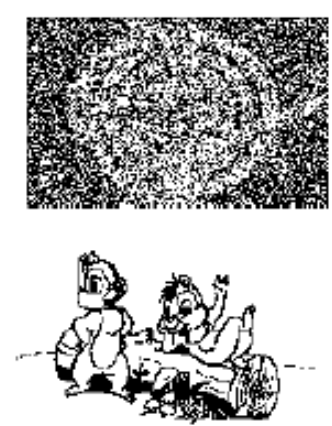

(b)
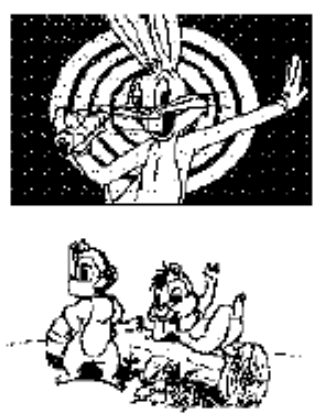

(c)

Gambar 2.5. Content-addressable memory (CAM) atau memori asosiatif.

Mengingat/ hafal pola (a), peran CAM adalah untuk mengembalikan (c) pola disimpan diberikan versi lengkap dari adanya gangguan (b).

Dengan asumsi bahwa waktu evolusi sistem fisik dapat dijelaskan oleh satu set umum koordinat, maka titik dalam ruang, yang disebut state space, mewakili kondisi sistem. Oleh karena itu, persamaan gerak dari sistem menggambarkan aliran keadaan di ruang. Dengan asumsi sistem juga mempunyai aliran yang bias dilakukan terhadap lokal stabil poin dari mana saja dalam lingkungan yang diberikan dari titik-titik yang stabil, sistem ini menjadi sangat berguna sebagai content-addressable memories. Model neuron asli yang digunakan oleh Hopfield (1982) adalah bahwa dari McCulloch dan Pitts (1943), dengan output dapat berupa '0' atau ' 1 ', dan masukan yang eksternal dan dari neuron lain juga. Dengan demikian, analisis jaringan dengan full back-kopling yang terlibat, yang adalah, jaringan berulang (seperti yang diilustrasikan pada Gambar 2.6). Fitur penting lainnya dari jaringan Hopfield adalah penyimpanan (instead of iterative learning) dari memori sistem, dan penggunaan prosedur asynchronous pengambilan memori.

\section{Aplikasi Neurocomputing}

Aplikasi Neurocomputing sangat beragam, dapat ditemukan di dunia kedokteran, geodesi, ekonomi, pertanian dan lain-lain. Untuk menggambarkan penerapan jaringan perceptron, mempertimbangkan dua masalah di bawah ini. Pertama misalnya: - masalah klasifikasi sederhana - menggambarkan potensi dari perceptron untuk mewakili fungsi Boolean, dan contoh kedua - pengenalan karakter -menggambarkan kemampuan untuk mengenali satu set sederhana karakter biner.

\subsection{Klasifikasi Masalah Sederhana}

Pertimbangkan permasalahan dalam menggunakan simple perceptron dengan single neuron untuk mewakili fungsi AND. Data pelatihan dan interpretasi grafis diperlihatkan pada Gambar 3.1. Pelatihan patters yang akan digunakan sebagai masukan untuk Algo 1 adalah, dalam notasi matriks: 


$$
\mathbf{X}=\left[\begin{array}{llll}
0 & 0 & 1 & 1 \\
0 & 1 & 0 & 1
\end{array}\right] \quad \mathbf{d}=\left[\begin{array}{llll}
0 & 0 & 0 & 1
\end{array}\right]
$$

\begin{tabular}{c|c|c}
\multicolumn{2}{c|}{ Inputs } & Output \\
\hline$x_{1}$ & $x_{2}$ & $x_{1}$ AND $x_{2}$ \\
0 & 0 & 0 \\
0 & 1 & 0 \\
1 & 0 & 0 \\
1 & 1 & 1
\end{tabular}

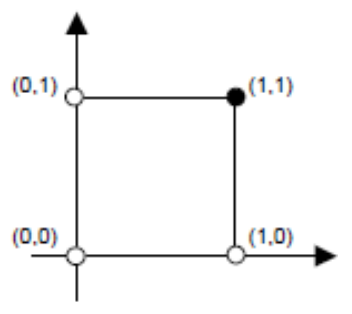

Gambar 3.1. Fungsi AND dan Representasi Grafis.

Batas antara nilai-nilai dari $\mathrm{x}_{1}$ dan $\mathrm{x}_{2}$ yang jaringan menyediakan respon '0' (tidak termasuk dalam kelas) dan nilai-nilai untuk yang merespon jaringan '1' (termasuk kelas) adalah garis pemisah yang diberikan oleh $\mathrm{x}_{1} \mathrm{w}_{1}+\mathrm{w}_{2} \mathrm{x}_{2}+\mathrm{b}=0$. (1)

Sebagai fungsi aktivasi jaringan adalah ambang batas dengan $\theta=0$, persyaratan untuk respon positif dari unit output yang input bersih yang diterima lebih besar dari atau sama dengan nol, yaitu, $\mathrm{x}_{1} \mathrm{w}_{1}+\mathrm{w}_{2} \mathrm{x}_{2}+\mathrm{b} \geq 0$. Selama pelatihan, nilainilai $\mathrm{w}_{1}, \mathrm{w}_{2}$ dan $\mathrm{b}$ adalah ditentukan sehingga jaringan akan menyajikan respon yang benar untuk semua data pelatihan.

Untuk mempermudah, tingkat belajar diatur ke $1, \alpha=1$, dan nilai awal untuk bobot dan bias diambil menjadi nol, $\mathrm{w}=\left[\begin{array}{ll}0 & 0\end{array}\right]$ dan $\mathrm{b}=0$ Dengan menjalankan Algo 1 dengan $\mathrm{X}$, d dan parameter lainnya yang diberikan di atas, nilai berikut diperoleh untuk perceptron jaringan dengan satu output. $\mathrm{w}_{1}=2 ; \mathrm{w}_{2}=1 ; \mathrm{b}=-3$.

Dengan mengganti nilai-nilai ini dalam persamaan garis untuk neuron ini maka akan diperoleh $2 \mathrm{x}_{1}+1 \mathrm{x}_{2}-3=0$. Untuk setiap pasangan data pelatihan, mengikuti ui masukan bersih, $i=1, \ldots, N$, dihitung: $u=[-3,-2,-1,0]$. Oleh karena itu, respon jaringan, $y=f(u)$, untuk setiap pola input $y=[0,0,0,1]$, mewujudkan fungsi AND yang diinginkan.

Garis keputusan antara dua kelas dapat ditentukan dengan mengisolasi variabel x2 sebagai fungsi dari variabel lainnya dalam Persamaan (1),

$$
x_{2}=-\frac{w_{1}}{w_{2}} x_{1}-\frac{b}{w_{2}}=-2 x_{1}+3 \text {. }
$$

Nilai-nilai ini menentukan garis keputusan di bawah ini, seperti yang digambarkan pada Gambar 3.2. Dua isu penting dapat melihat di sini. Pertama, respon jaringan tergantung pada nilai awal dipilih untuk bobot dan bias. Kedua, tidak ada yang benar tunggal respon untuk satu set data pelatihan yang diberikan. Ini dan isu-isu penting lainnya dalam jaringan saraf pelatihan akan dibahas kemudian. 


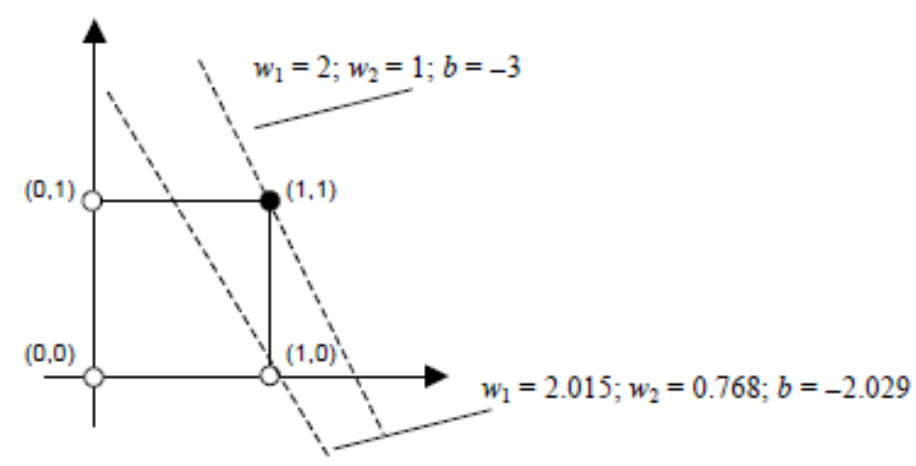

Gambar 3.2. Garis Keputusan untuk jaringan perceptron sederhana mewujudkan fungsi logika AND.

\subsection{Structured Random Distribution}

Untuk menggambarkan perilaku SOM, mempertimbangkan set input data terdiri dari 500 bidimensional sampel merata selama interval $[-1,1]$, seperti yang digambarkan dalam Gambar 3.3. (a). Pola masukan yang dinormalisasi untuk interval satuan sehingga kebohongan distribusi mereka pada permukaan lingkaran satuan. Sebuah grid bi-dimensi dengan 6 baris dan 6 kolom $(6 \times 6)$ adalah bekas. Gambar 37 (b) ke (d) menunjukkan tiga tahapan proses adaptif sebagai jaringan belajar untuk mewakili distribusi input.

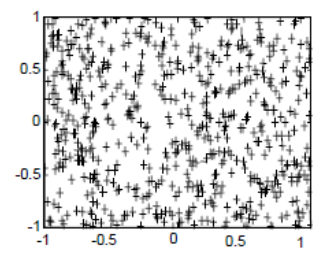

(a)

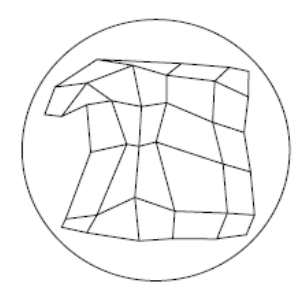

(c)



(b)

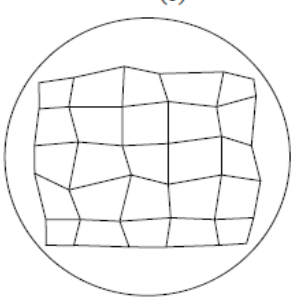

(d)

Gambar 3.3. Penerapan jaringan SOM dengan grid bi-dimensi untuk input data terdistribusi secara acak set. (a) mengatur Input data untuk SOM bi-dimensi. (b) Kondisi grid setelah 1000 iterasi. (c) Kondisi dari grid setelah 5000 iterasi. (d) Grid setelah 10000 iterasi.

\subsection{Fundamental Memories for the Discrete Hopfield network}

Untuk menggambarkan kemampuan error-correcting dari jaringan Hopfield, pertimbangkan sama masalah pengenalan karakter dibahas dalam Bagian 4.2.4 dan diilustrasikan dalam Gambar 3.4. Dalam kasus ini, pola diasumsikan bipolar, 
yaitu, terdiri dari sedikit -1 (gelap abu-abu) atau 1 (abu-abu terang). Karena setiap pola memiliki $\mathrm{m}$ dimensi $=120$, jaringan yang digunakan dalam percobaan memiliki $\mathrm{m}=120$ neuron, dan karena itu $\mathrm{m} 2-\mathrm{m}=12.280$ sambungan.
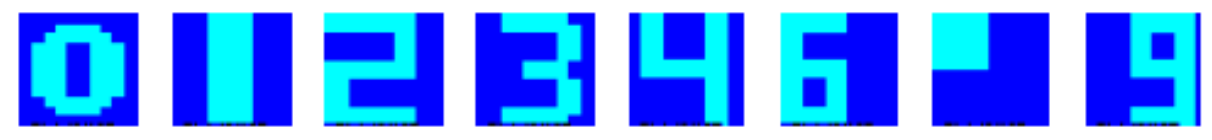

Gambar 3.4. Memori Fundamental untuk jaringan Diskrit Hopfield

Untuk menguji kemampuan penyimpanan jaringan, pola yang sama (memori fundamental) dapat disajikan ke jaringan. Untuk menunjukkan kemampuan errorcorrecting-nya, memperkenalkan gangguan acak dalam pola oleh independen membalikkan setiap pixel dari pola dari 1 dengan -1, atau sebaliknya, dengan probabilitas yang diberikan. Pola yang rusak digunakan sebagai probe untuk jaringan.

\subsection{Neural Computing: Application in Non-Invasive Cancer Detection}

Diagnosis kanker non-invasif merupakan salah satu tantangan paling praktis tetapi sulit kedokteran kontemporer. Metode pencitraan modern telah baru-baru ini dikembangkan untuk membantu diagnosis kanker dengan membedakan antara jaringan yang sakit dan normal. Jaringan saraf, paradigma pemrosesan informasi terinspirasi oleh cara otak manusia memproses informasi, dapat berhasil dilatih dengan sampel gambar tumor, untuk membedakan antara tumor jinak atau ganas. Tujuan penelitian ini adalah untuk menunjukkan efisiensi jaringan saraf dalam diagnosis non-invasif penyakit ganas, menggunakan endoskopi USG elastography film sampel mengenai tumor pankreas. Para pemerhati yang dimaksudkan disini terdiri dari ahli statistik dan peneliti di Data Mining (termasuk dokter) tertarik dalam aplikasi medis dibantu komputer. Tingkat menengah dari latar belakang komputasi saraf diperlukan untuk memahami kasus ini. (Florin Gorunescu, 2008)

Selain contoh di atas, masih banyak contoh penelitian aplikasi neurocomputing yang dilakukan oleh peneliti, baik di dalam maupun luar negeri, yang tidak dapat dituliskan satu persatu pada makalah ini.

\section{Cakupan Neurocomputing}

Jaringan saraf tiruan dapat, pada prinsipnya, menghitung fungsi yang dapat dihitung, yaitu, dapat melakukan segala sesuatu dengan komputer digital standar dan dapat dilakukan. Aplikasi praktis dari jaringan saraf paling sering menggunakan metode pembelajaran, di mana data pelatihan mencakup baik input dan output yang diinginkan atau hasil. Setelah pelatihan berhasil, input data dapat dapat disajikan ke jaringan yang kemudian digunakan untuk menghitung nilai output yang mendekati output yang diinginkan. Namun, untuk banyak aplikasi mungkin sulit untuk memilih yang tepat input data dan untuk kode data, jika perlu, sebagai nilai-nilai numerik.

Self-organizing feature maps, seperti yang dijelaskan dalam makalah, menemukan aplikasi dalam berbagai bidang, seperti kategorisasi tanpa pengawasan data 
(pengelompokan), pengenalan pola, penginderaan jauh, robotika, pengolahan informasi semantik, dan penemuan pengetahuan dalam database (data mining). Jaringan berulang telah secara luas diterapkan untuk time series prediksi, pengenalan pola, identifikasi sistem dan kontrol, dan bahasa alami pengolahan.

\section{Kesimpulan}

Sistem saraf merupakan salah satu sistem kontrol utama dari organisme hidup, dan bertanggung jawab, antara lain, untuk menerima rangsangan dari lingkungan, pengolahan, dan kemudian menunjukkan respon output. Sudah sangat berpengaruh dalam desain alat komputasi untuk pemecahan masalah yang menggunakan elemen neuron-seperti unit pengolahan utama.

Dalam bentuk yang disederhanakan, sistem saraf terdiri dari sel-sel saraf, terutama saraf terstruktur dalam jaringan neuron. Melalui modulasi sinaptik sistem saraf mampu menghasilkan representasi internal rangsangan lingkungan, yang melalui titik rangsangan ini menjadi tidak perlu untuk munculnya ide dan kreativitas. Self internal model mampu menghasilkan stimulatation. Jaringan syaraf tiruan yang dirancang sebagai model yang sangat abstrak berdasarkan model matematika sederhana dari neuron biologis. Perakitan neuron buatan dalam jaringan struktur memungkinkan penciptaan perangkat neurocomputational yang kuat, dengan aplikasi untuk beberapa domain, dari pengenalan pola kontrol.

Makalah ini memperkenalkan bidang jaringan saraf dengan menghadirkan kerangka untuk merancang ANN (model neuron, struktur jaringan dan algoritma pembelajaran), dan kemudian melanjutkan dengan review dari beberapa jenis yang paling terkenal dari jaringan saraf. Sebagian contoh aplikasi dari semua jaringan telah dibahas.

\section{Daftar Pustaka}

[1] Anderson, J. A. 1995, An Introduction to Neural Networks, The MIT Press

[2] Florin Gorunescu,2008, Neural Computing: Application in Non-Invasive Cancer Detection. http://www.bentley.edu/csbigs/vol1-2/gorunescu.pdf

[3] Fredric M. Ham, 2001, Principles of Neurocomputing for Science \& Engineering, McGraw-Hill.

[4] Haykin, S. 1999, Neural Networks: A Comprehensive Foundation, 2nd Ed., Prentice Hall.

[5] Hebb, D. O. 1949, The Organization of Behavior: A Neuropsychological Theory, New York: Wiley

[6] Hopfield, J. J. 1982, "Neural Networks and Physical Systems with Emergent Collective Computational Capabilities", Proc. of the Nat. Acad. of Sci. USA, pp. 2554-2558. 
[7] Hopfield, J. J. (1984), "Neurons with Graded Response Have Collective Computational Properties like those of Two-State Neurons", Proc. of the Nat. Acad. of Sci. USA, pp. 3088-3092.

[8] Kohonen, T. 1982, "Self-Organized Formation of Topologically Correct Feature Maps", Biological Cybernetics, pp. 59-69.

[9] Kohonen, T. 1990, "The Self-Organizing Map", Proceedings of the IEEE, , pp. 1464- 1480 .

[10] Minsky, M. L. and Papert, S. A. 1969, Perceptrons, MIT Press.

[11] Rosenblatt, F. 1962, Principles of Neurodynamics, Spartan Books.

[12] Trappenberg, T. 2002, Fundamentals of Computational Neuroscience, Oxford University Press.

[13] Widrow, B. and Hoff, M. E. Jr. 1960, Adaptive Switching Circuits, WESCON Convention Record, pp. 96-104. 